JULIAN BELL 



\section{JULIAN BELL}

From Bloomsbury to

the Spanish Civil War

Peter Stansky and

William Abrahams

Stanford University Press

Stanford, California 
(C) 2012 Peter Stansky. All rights reserved.

Excerpts from The Letters of Virginia Woolf, I: I888-I9I2; II: 19I2-I922; III: I923-1928; IV: 1929-193I; V: 1932-1935; VI: 1936-194I, copyright ( ) 1975, 1976, 1978, I979, I980 by Quentin Bell and Angelica Garnett, reprinted by permission of Houghton Mifflin Harcourt Publishing Company. Excerpt from The Diary of Virginia Woolf, I: 19I5-I919; II: 1920-1924; III: 1925-I930, IV: 193I-1935, V: I936-I94I, copyright (C 1977, 1978, I980, 1982, 1984 by Quentin Bell and Angelica Garnett, reprinted by permission of Houghton Mifflin Harcourt Publishing Company.

No part of this book may be reproduced or transmitted in any form or by any means, electronic or mechanical, including photocopying and recording, or in any information storage or retrieval system without the prior written permission of Stanford University Press.

Printed in the United States of America on acid-free, archival-quality paper

Library of Congress Cataloging-in-Publication Data

Stansky, Peter, author.

Julian Bell : from Bloomsbury to the Spanish Civil War / Peter Stansky and William Abrahams.

pages $\mathrm{cm}$.

Includes bibliographical references and index.

ISBN 978-0-8047-7413-0 (cloth : alk. paper)

I. Bell, Julian, I908-1937. 2. Poets, English—2oth century—Biography.

3. Bloomsbury group. I. Abrahams, William Miller, author. II. Title.

PR6003.E434Z855 2012

$821^{\prime} .912-\mathrm{dc} 22$

Typeset at Stanford University Press in I0.5/15 Adobe Garamond 